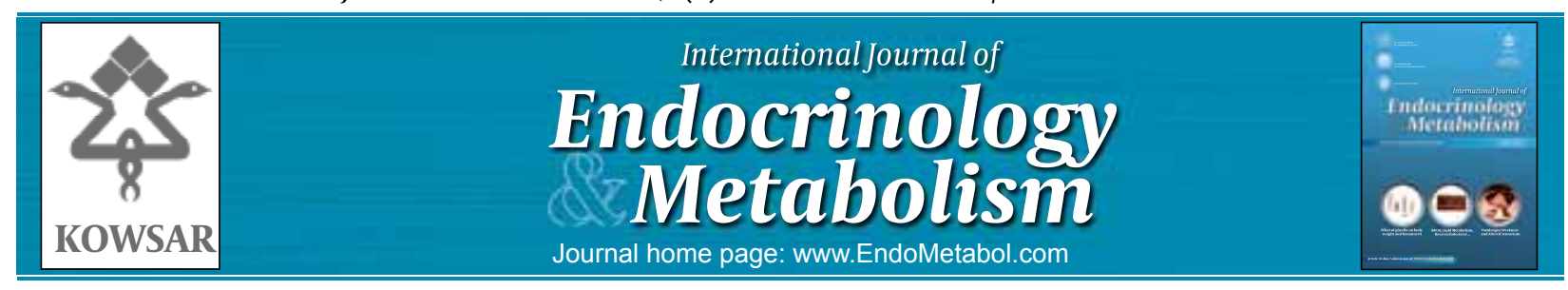

\title{
Metabolic Programming: Origin of Non-Communicable Diseases in Early Life Nutrition
}

\author{
Ali Kiani i ${ }^{1 *}$, Mette Olaf Nielsen ${ }^{2}$ \\ ${ }^{1}$ Animal Science Group, Lorestan University, Khoramabad, IR Iran \\ ${ }^{2}$ Department of Basic Animal and Veterinary Sciences, Faculty of Life Sciences, University of Copenhagen, Frederiksbery, Denmark
}

\begin{tabular}{|c|c|}
\hline A R T I C C L E I I N F O & A B S T R A C T \\
\hline $\begin{array}{l}\text { Article type: } \\
\text { Review Article }\end{array}$ & $\begin{array}{l}\text { Metabolic programming (MP) is defined the induction, deletion, or impaired develop- } \\
\text { ment of a somatic structure or "setting" of a physiological system by an early life stimu- }\end{array}$ \\
\hline $\begin{array}{l}\text { Article history: } \\
\text { Received: } 20 \text { Feb } 2011 \\
\text { Revised: } 08 \text { Jun } 2011 \\
\text { Accepted: } 30 \text { Jun } 2011\end{array}$ & $\begin{array}{l}\text { lus. Epidemiological and animal studies support the theory that suboptimal intrauterine } \\
\text { conditions are associated with non-communicable disease (NCD) in adulthood. Using } \\
\text { ovine models, we investigated the long-term consequences of late gestation undernutri- } \\
\text { tion on glucose-insulin axis function and energy metabolism. We found that early life } \\
\text { undernutrition had life-lasting consequences on insulin-secretory and adipose lipolytic }\end{array}$ \\
\hline $\begin{array}{l}\text { Keywords: } \\
\text { Metabolic Programming } \\
\text { Energy Metabolism } \\
\text { Chronic Disease }\end{array}$ & $\begin{array}{l}\text { suboptimal intrauterine nutrition impairs energy expenditure (EE) in gestation, appar- } \\
\text { ently via an increase in the energy cost of conceptus development. Our findings, and } \\
\text { those of other studies, support the hypothesis that energy balance is, to a certain extent, } \\
\text { programmed early in life, presumably through appetite, EE, physical activity, and/or dis- } \\
\text { proportional postnatal growth programming. }\end{array}$ \\
\hline
\end{tabular}

Implication for health policy/practice/research/medical education:

Metabolic programming is an emerging area of science dealing with the origins of non-communicable diseases. Impaired development due to suboptimal intrauterine conditions may cause short term as well as long term effects on the function of the organisms subsequently determining the health and disease in later life. Reading this review article is recommended to all family physicians, epidemiologists, nutritionists, animal scientist, endocrinologists and health policy makers.

Please cite this paper as:

Kiani A, Nielsen MO. Metabolic Programming: Origin of Non-Communicable Diseases in Early Life Nutrition. Int J Endocrinol Metab. 2011;9(3):409-15.DOI: 10.5812/Kowsar.1726913X.3366

\section{Metabolic Programming}

Metabolic programming (MP), or developmental plasticity, is a term used to describe the induction, deletion, or impaired development of a somatic structure or "setting" of a physiological system by an early life stimulus operated at a "critical" or "sensitive" period during development (1). Impaired development may cause shortterm, as well as long-term or permanent, effects on the structure or function of the organism (2). MP has been of great interest among epidemiologists and animal sci-

* Corresponding author: Kiani A, Animal Science Group, Faculty of Agricultural Sciences, Lorestan University, Khoramabad, IR Iran. Tel: +986614200012, Fax:+98-6614200289,E-mail:arkashkia@gmail.com,kiani.a@ lu.ac.ir

DOI:10.5812/Kowsar.1726913X.3366

Copyright $\odot 2011$ Kowsar M.P.Co. All rights reserved. entists since epidemiological observations have revealed that the manifestation of non-communicable disease (NCD; obesity, type-2 diabetes, cardiovascular disease, stroke, cancer, chronic respiratory disease, and renal disease) in adulthood can have their origin in suboptimal intrauterine conditions. The Developmental Origin of Health and Disease Society (DOHaD Society), an international, rapidly expanding society, is dealing with multidisciplinary research in the area of MP (www.dohadsoc. org). One of the aims of the DOHaD Society is to promote co-ordination of a global research strategy for scientific exploration of the link between early life conditions and NCDs in later life.

Twenty years ago, Hales and Barker, in an attempt to explain the association between poor fetal and infant growth and risk of impaired glucose tolerance and the 
metabolic syndrome in adult life, proposed the "thrifty phenotype hypothesis." According to their hypothesis, if, during intrauterine development, the supply of nutrients is scarce, the fetus is programmed to spare nutrients and become thrifty, even if nutrient availability becomes abundant later in life $(3,4)$. These alterations could be valuable for survival in a poor nutritional environment, but may lead to disease if the postnatal nutritional environment does not match the prenatal life conditions. In short, in their hypothesis they suggested that poor fetal and infant nutrition, mainly via maternal malnutrition, can act as the stress that triggers the metabolic programming process and suppresses the fetal growth. They also proposed that the key element linking poor early nutrition to later type-2 diabetes was poor development of pancreatic $\beta$-cell mass during fetal life. In an updated version of the thrifty phenotype hypothesis, presented in 2001, Hales and Barker included the intergenerational effects of poor maternal nutrition. The poorly nourished mother forecasts the nutritional environment into which the fetus will be born.

The metabolic processes in the fetus are set in motion, such that postnatal metabolism is adapted to survival under conditions of poor nutrition. These alterations could be valuable for survival in a poor nutritional environment, but may lead to diseases if the postnatal nutritional environment does not match the prenatal life conditions (5). They proposed that the growth, metabolism, and vasculature of the fetus may be affected by impairment in the mother's development and growth, maternal malnutrition, maternal hyperglycemia, and other maternal/placental influences. In summary, they proposed that poor fetal and infant growth leads to subsequent development of type 2-diabetes and the metabolic syndrome (5).

Developmental plasticity theory is a modification which attempts to clarify the original observed association between suboptimal conditions early in life and metabolic disorders in adulthood. According to developmental plasticity theory, permanent characteristics of an individual are founded based on environmental conditions early in life, which modify the developmental trajectory of that individual. Individuals developmentally adapted to one environment may therefore be at risk when exposed to another later in life. (6).

\section{NCDs Are a Worldwide Challenge}

The increased prevalence of NCD has become a major health issue in both developed and developing countries. According to the World Health Organization (WHO), nearly $80 \%$ of the 36 million global deaths were due to NCD in 2008 (63\% of all deaths), and these occurred in low- and middle-income countries (7). The WHO predicts that NCD will show a significant increase, of about $15 \%$ globally from 2010, to reach 44 million deaths by 2020 . Currently, 346 million people are suffering from diabe- tes in developed and underdeveloped nations (8). Overweight and obesity is increasing among both men and women $(7,9)$ in developed $(10,11)$ as well as in developing countries (12-16), and the shift towards earlier onset and the development of childhood obesity is particularly alarming.

In Iran, a nutritional transition toward a western lifestyle has occurred in recent decades. Along with the recent nutritional transition, the prevalence of diet-related NCD has increased in the Iranian population. Cardiovascular diseases are the leading cause of deaths in Iran, accounting for $50 \%$ of all deaths per year. More than 3.5 million people (about $5 \%$ of the Iranian population) suffer from diabetes (17). Prevalence of overweight among urban regions was higher, compared with corresponding values for rural areas (16). Prevalence of obesity, especially among Iranian women, is even higher than their counterparts in western countries (18). High prevalence of the metabolic syndrome (19), particularly among overweight adolescents (20), has also been reported.

\section{Early Life Undernutrition as a Program- ming Stimulus}

The first evidence supporting early nutrition as a stimulus for MP comes directly from epidemiological studies in human populations, particularly from the Dutch Winter Famine during World War II. During the Dutch famine, women exposed to undernutrition during late gestation gave birth to offspring with reduced birth size and these infants were found to have an increased risk of developing glucose intolerance (21) and obesity (22) in adult life. Many other studies have confirmed a clear adverse relationship between low birth weight and risk of type-2 diabetes (23-27), obesity (28), insulin resistance $(29,30)$, cardiovascular disease (31-34), elevated blood pressure (35-38), and elevated fat-free body mass in adults (39).

The second line of evidence is based on current knowledge of the regulation of mammalian fetal growth. In mammals, 2 major determinants of the size of the baby are uterus size and food supply from the mother. The size of the baby is regulated according to the size of the mother. A convincing study about influence of maternal size on fetal and postnatal growth has been conducted with the horses, where Shetland ponies were crossed with Shire horses. At birth, the foals were approximately proportional in weight to the weights of their mothers. Maternal regulation of fetal growth was very marked and obscured any genetic differences. (39). Nutritional animal studies provide the third line of evidence supporting nutrition as the programming stimulus (40-43). There are different kinds of animal model that have been used to study the underlying mechanisms of MP, which for ethical reasons cannot be studied in controlled human experiments. Later on in this report, we review these animal studies briefly.

What are the early life causative factors inducing de- 
velopmental programming? Hormones such as glucocorticoids, insulin, and leptin are, thus far, the main candidates for the underlying mechanism of MP. Increased exposure to glucocorticoids (cortisol) can be one of the direct causative mechanisms linking adverse exposure to fetal adaptation. The fetus is normally protected against corticocorticoids due to maternal and placental corticosteroid binding globulin and placental type 1 and type 2 11 -hydroxysteroid dehydrogenase (11ßHSD1 and 11ßHSD2). However, under maternal stress or exogenous corticosterone administration, these protective mechanisms become deficient or fail $(44,45)$. Thus, excessive glucocorticoid exposure during gestation may result in long-term effects in different organs. Leptin and insulin can cross the placental/fetal barrier and affect development of the neural system important in energy metabolism. For example, leptin controls the development of the hypothalamic appetite regulatory system (46).

It has been postulated that MP can be associated with epigenetic changes, resulting in altered phenotypic expression of the genome $(47,48)$. Recently it is has been shown that epigenetic mechanisms are involved in different pathophysiological conditions, including the metabolic syndrome $(49,50)$. Epigenetic modifications fit well with the fact that the phenotype is altered in programmed individuals. However, it is puzzling that, in programmed individuals, metabolic and endocrine phenotypes are virtually absent at birth (except for changes in birth weight) and in early life, and only become increasingly manifested with age.

\section{Nutritional Animal Models in MP}

Possibilities such as manipulating the diet, controlling food intake and environmental conditions, establishing challenge-response data, performing frequent noninvasive measurements and invasive procedures (e.g. sampling by biopsy), and providing multiple data points within the same animal are some of the advantages of experimental animal models. Studies in rodent models, the most common animal models used in the field of MP, have been extensively reviewed previously (43, 5153). Ovine models and their contribution to our understanding of the mechanisms underlying MP have been discussed recently (54-56). Thus, in this review, we do not intend to discuss animal models in great detail (for further discussion about animal models, see (57)). Sheep are comparable to humans in terms of birth weight (2.5-5.5 $\mathrm{kg}$ ), litter size (singletons or twins), gestation period (term $=147$ days), body size, developmental trajectory, and timing of organ development. For instance, a full complement of cardiomyocytes and nephrons occurs at birth in both sheep and humans (58). Sheep are relatively easy to manipulate surgically, and this permits studies on the effects of suboptimal intrauterine environments directly on the fetus. Biomedical research using a pregnant ovine model showed that maternal undernutrition during the periconceptional period results in altered fetal hypothalamic-pituitary-adrenal (HPA) axis development, an increased rate of premature birth, and altered fetal pancreatic function, insulin signaling, and amino acid metabolism (59). Restricted nutrition in the early part of pregnancy altered postnatal muscle development, fat deposition, cardiovascular regulation, and HPA axis function in the offspring. Maternal undernutrition during mid-gestation resulted in altered growth, adiposity, and glucose tolerance in male offspring (60). Undernutrition from day 0 to 95 during gestation programmed aspects of cardiovascular control and adipocyte function in adult sheep (61). Undernutrition during late gestation (from day 110 until term) affected intermediary metabolism and, in particular, glucose-insulin homeostasis in offspring (62). In our ovine model we investigate the long-term consequences of late gestation undernutrition (from day 100 until term) on glucose-insulin axis function, growth hormone-insulin-like growth factor-1 (GH-IGF-1) axis function, HPA axis function, and energy metabolism. Pregnant ewes were fed either adequate (100\%) or restricted (60\%) intake during late gestation. Postnatally, lambs were kept and reared under the same environmental conditions. We showed that offspring (about 6 months of age) born to undernourished mothers had lower insulin-secretory capacity, an increased adipose lipolytic capacity (63), and signs of perturbations in ketone body metabolism during fasting (64). After 3 years, in spite of significant reduction in body weight (16\% lighter), early life undernutrition did not affect pregnancy outcome in ewes born to mothers with restricted dietary intake (total lamb birth weight). This was somewhat surprising, since litter weight is normally considered to be related to the size of the dam (65). Furthermore our studies showed that nutritional restriction during early life impaired the metabolic rate of a adult pregnant ewes later in life (discussed later in this article) (66).

With the aim of overcoming adverse phenotypic outcomes driven by early life pre- and postnatal exposure to dietary interventions, a special ovine protocol (Danish ovine model) was designed by Nielsen and her research team at Copenhagen University. In this model, ewes are fed adequately or restrictedly during the last trimester of pregnancy, and lambs born to these ewes receive either a normal milk replacer (19\% fat and $24 \%$ protein) or a highfat (38\% fat and $2.1 \%$ protein) diet for the first 6 months of life. Thereafter, the animals are fed conventionally. The model has shown that skeletal muscle mitochondria of offspring are affected by both undernutrition during late gestation, and a high-fat diet in early postnatal life. Late gestational undernutrition programmed a reduction in the mitochondrial maximal oxygen uptake $\left(\mathrm{VO}_{2} \mathrm{max}\right)$ in adult, 24-month-old sheep, but not in adolescent animals (6-month-old). The postnatal high-fat diet, on the other hand, induced a pronounced increase in the respiratory coupling ratio and $\mathrm{VO}_{2}$ max, effects, which were reversible by exposure to a normal diet from 6 months 
to 2 years (67).

\section{Energy Metabolism and MP}

The balance between energy intake and energy expenditure (EE) is controlled through the appetite regulatory networks in the hypothalamus. There are a range of appetite regulatory neuropeptides, which either stimulate or inhibit appetite (68). In humans as well as in sheep, the neural network of the appetite regulatory system develops during late gestation $(69,70)$, a critical period during which the appetite regulatory network in the fetal hypothalamus is susceptible to change in fetal nutrient supply $(71,72)$. Since experimental studies in animals support the concept that prenatal and postnatal dietary interactions may give rise to later obesity (73-75), susceptibility of energy balance through early life programming has also received much interest in the scientific community $(42,50,76,77)$. Possible pathways of energy balance programming include permanent alteration in appetite regulation, EE, and physical activity, and disproportional postnatal growth (Figure 1). Different nutritional inputs can influence an immature hypothalamic appetite network (78). Interestingly, an enhanced nutritional plane during late gestation in sheep influenced early appetite behavior (72). A key mediator of this effect is leptin and its effects on hypothalamic reorganization. It has been shown that neonatal exposure to leptin can simply reverse both the genetically predetermined hyperphagic and obese ob/ob mouse phenotype and the dietary-induced obese and lethargic rat phenotype (79, 80). Recently, it has been shown in sheep that fetal hypothalamic leptin signaling is altered by increased adiposity and leptinemia (81).These prenatal changes in appetite regulating networks in the hypothalamus could impact the regulation of postnatal energy balance.

There is evidence both in humans (82) and in animals (83) that cost of pregnancy in terms of energy is closely related to the maternal energy status. The fact that mothers in different countries have enormously different energy intakes (82) proves that drastic metabolic adaptations in both the pregnant mother and/or her fetus must take place (84). In pregnant women, energy-sparing adaptive mechanisms have been observed (82), and similarly, in sheep we have shown that intake restriction during

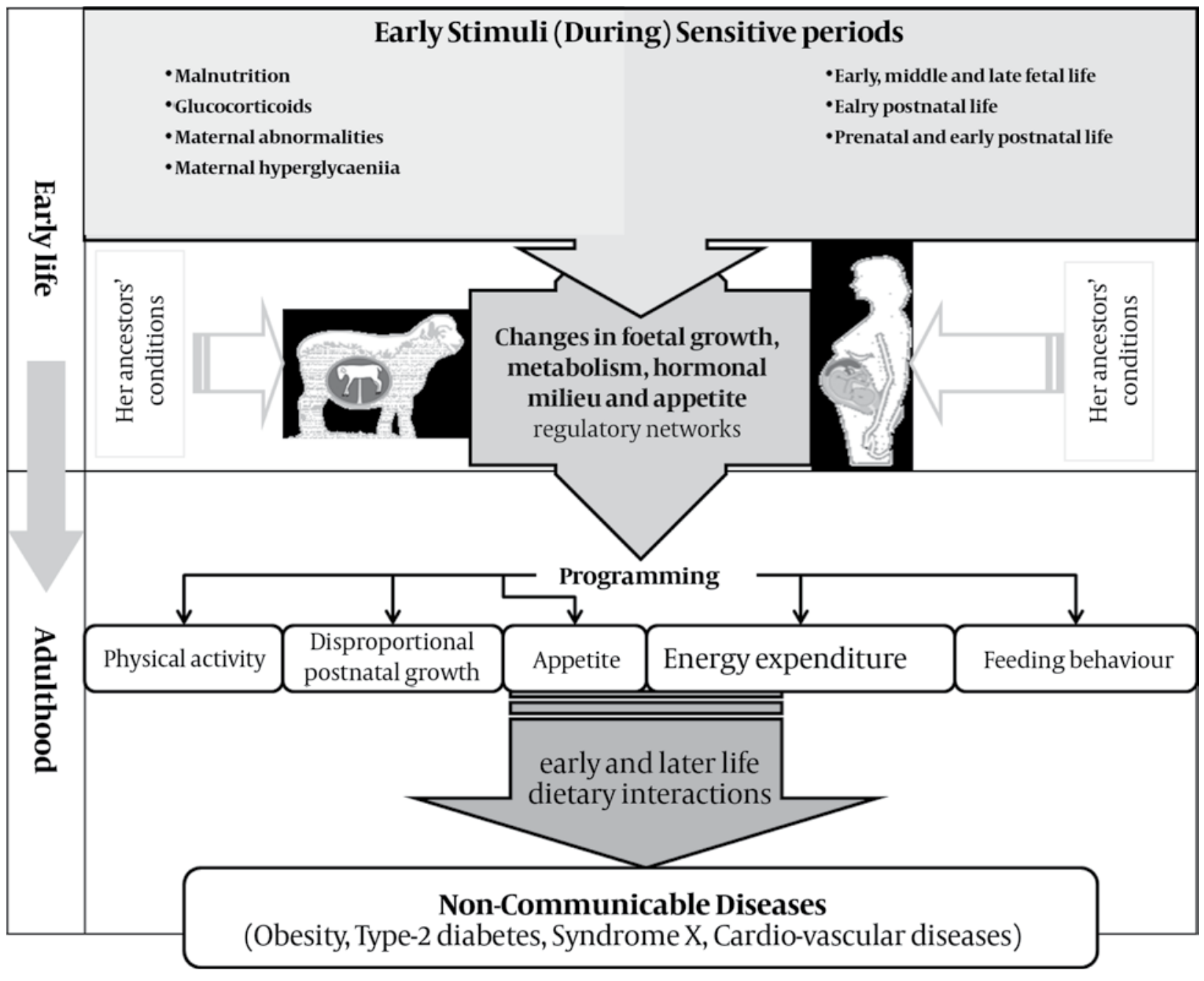

Figure 1. Schematic representation of Metabolic Programming of Energy Metabolism and Related NCDs 
late gestation reduces EE of gestation (83). On the other hand, a developing fetus is capable of adapting cellular and body functions upon exposure to suboptimal conditions. One clear example of fetal adaptation is the reaction of the fetus to hypoxemia. When a fetus becomes hypoxic, the fetal blood flow is redistributed towards the brain and away from other organs. The weight of the fetal liver and thymus decreases due to late gestation maternal undernutrition in sheep (85). Even though functional metabolic adaptation in maternal and fetal energy metabolism may presumably support fetal growth, fetal compensations that either deprive organs or alter functions may impact energy balance later in life. Basically, during gestation, the fetus is growing and meanwhile EE increases in humans $(86,87)$ and in animals $(88)$. The increase in EE during gestation has 3 different origins: 1) EE required for body maintenance; 2) EE required for conceptus growth; and 3) EE from increased metabolism in the non-gravid tissues (88). Metabolic features and endocrine systems involved in regulation of energy intake and expenditure are indeed altered in undernourished dams and fetuses. However, it is as yet unknown whether adaptations in gestational energy balance can induce permanent alterations in energy balance, in terms of intake and expenditure in later life.

We conducted a long-term study in order to investigate whether late gestational undernutrition programs the EE of gestation during adulthood in the offspring. Offspring were maintained for 3 years. When the female offspring became pregnant adult ewes, they were fed adequately or restrictedly during late gestation of their second parity. Accordingly, offspring were categorized into 3 groups: Adequate-Adequate (AA), Adequate-Restricted (AR), and Restricted-Restricted (RR), based on their early life and current nutrition status. At 2 weeks prepartum, the EE of gestation was measured. Surprisingly, RR ewes did not reduce the EE of gestation in response to late gestational feed restriction, in contrast to the AR ewes. This finding indicates that nutritional restriction during early life may impair the ability of adult pregnant ewes to adapt to changes in metabolic rate. Furthermore, the failure of RR ewes to reduce the EE of gestation in response to late gestation nutrient restriction was apparently related to the higher EE for conceptus development. Even though the underlying mechanism for the apparent loss of metabolic adaptive response in adult ewes subjected to early life undernourishment is at present unknown, it might be interpreted as a thrifty way by which nutritional challenges are handled by ewes who were nutritionally-restricted in early life. Unfortunately, feed intake and physical activity of animals were not recorded. Studies in rats showed that prenatal high protein exposure increases adiposity and decreases EE in young rats $(89,90)$. Increased food intake and reduced physical activity has also been reported to be induced by maternal undernourishment or protein restriction during pregnancy in rats $(91,92)$. These studies are not yet conclusive, and thus more clinical and epidemiological studies are needed to elucidate whether suboptimal conditions in early life can program energy metabolism (intake, expenditure, physical activity, feeding behavior, and appetite) in humans.

\section{Challenges and Future Research}

A dramatic global increase in the prevalence of NCD has occurred in recent decades. Taking into consideration that the cost of hospitalization and healthcare expenditure is higher for NCD, urgent preventive strategies and multidisciplinary research approaches are needed to tackle the increasing prevalence of NCD amongst the Iranian population. More attention to the research into MP may help us to slow down the increase in NCD, and particularly, the manifestation of NCD in adulthood, which may originate in suboptimal intrauterine conditions. Both epidemiological and animal studies are required to understand the pathophysiological underlying mechanisms. Because energy balance has an obvious relation to NCD, more focused research in MP will also help us to challenge the increasing rate of NCD in our community.

\section{Acknowledgments}

None declared.

\section{Financial Disclosure}

None declared.

\section{Funding/Support}

None declared.

\section{References}

1. Lucas A. Programming by early nutrition: an experimental approach. J Nutr. 1998;128(2 Suppl):401S-6S.

2. McMillen IC, Robinson JS. Developmental origins of the metabolic syndrome: prediction, plasticity, and programming. Physiol Rev. 2005;85(2):571-633.

3. Hales CN. Fetal and infant growth and impaired glucose tolerance in adulthood: the "thrifty phenotype" hypothesis revisited. Acta Paediatr Suppl.1997;422:73-7.

4. Hales CN, Barker DJ. Type 2 (non-insulin-dependent) diabetes mellitus: the thrifty phenotype hypothesis. Diabetologia. 1992;35(7):595-601.

5. Hales CN, Barker DJ. The thrifty phenotype hypothesis. Br Med Bull. 2001;60:5-20.

6. Bateson P, Barker D, Clutton-Brock T, Deb D, D'Udine B, Foley RA, et al. Developmental plasticity and human health. Nature. 2004;430(6998):419-21.

7. World Health Organization. Global status report on noncommunicable diseases 2010. Description of the Global Burden of NCDs, Their Risk Factors and Determinants Geneva: World Health Organization. 2011

8. Singh R, Shaw J, Zimmet P. Epidemiology of childhood type 2 diabetes in the developing world. Pediatr Diabetes. 2004;5(3):15468.

9. VanItallie TB. Worldwide epidemiology of obesity. Pharmacoeconomics. 1994;5(Suppl 1):1-7.

10. Belanger-Ducharme F, Tremblay A. Prevalence of obesity in Canada. Obes Rev. 2005;6(3):183-6.

11. Martinez JA, Moreno B, Martinez-Gonzalez MA. Prevalence of 
obesity in Spain. Obes Rev. 2004;5(3):171-2.

12. Al-Almaie SM. Prevalence of obesity and overweight among Saudi adolescents in Eastern Saudi Arabia. Saudi Med J. 2005;26(4):607-11.

13. Bener A. Prevalence of obesity, overweight, and underweight in Qatari adolescents. Food Nutr Bull. 2006;27(1):39-45.

14. Chu NF. Prevalence of obesity in Taiwan. Obes Rev. 2005;6(4):2714.

15. Kim DM, Ahn CW, Nam SY. Prevalence of obesity in Korea. Obes Rev. 2005;6(2):117-21.

16. Rashidi A, Mohammadpour-Ahranjani B, Vafa MR, Karandish M. Prevalence of obesity in Iran. Obes Rev. 2005;6(3):191-2.

17. Azizi F. Diabetes care and prevention in Iran. Diabetes Voice. 2005;50(4):15-7.

18. Bahrami H, Sadatsafavi M, Pourshams A, Kamangar F, Nouraei $\mathrm{M}$, Semnani S, et al. Obesity and hypertension in an Iranian cohort study; Iranian women experience higher rates of obesity and hypertension than American women. BMC Public Health. 2006;6:158.

19. Azizi F, Salehi P, Etemadi A, Zahedi-Asl S. Prevalence of metabolic syndrome in an urban population: Tehran Lipid and Glucose Study. Diabetes Res Clin Pract. 2003;61(1):29-37.

20. Esmaillzadeh A, Mirmiran P, Azadbakht L, Etemadi A, Azizi F High prevalence of the metabolic syndrome in Iranian adolescents. Obesity (Silver Spring). 2006;14(3):377-82.

21. Ravelli AC, van der Meulen JH, Michels RP, Osmond C, Barker DJ, Hales $\mathrm{CN}$, et al. Glucose tolerance in adults after prenatal exposure to famine. Lancet.1998;351(9097):173-7.

22. Ravelli AC, van der Meulen JH, Osmond C, Barker DJ, Bleker OP. Obesity at the age of $50 \mathrm{y}$ in men and women exposed to famine prenatally. Am JClin Nut. 1999;70(5):811-6.

23. Curhan GC, Chertow GM, Willett WC, Spiegelman D, Colditz GA, Manson JE, et al. Birth weight and adult hypertension and obesity in women. Circulation. 1996;94(6):1310-5.

24. Curhan GC, Willett WC, Rimm EB, Spiegelman D, Ascherio AL, Stampfer MJ. Birth weight and adult hypertension, diabetes mellitus, and obesity in US men. Circulation.1996;94(12):3246-50.

25. Lawlor DA, Davey Smith G, Clark H, Leon DA. The associations of birthweight, gestational age and childhood BMI with type 2 diabetes: findings from the Aberdeen Children of the 1950 s cohort. Diabetologia. 2006;49(11):2614-7.

26. McCance DR, Pettitt DJ, Hanson RL, Jacobsson LT, Knowler WC, Bennett PH. Birth weight and non-insulin dependent diabetes: thrifty genotype, thrifty phenotype, or surviving small baby genotype? BMJ.1994;308(6934):942-5.

27. Rich-Edwards JW, Colditz GA, Stampfer MJ, Willett WC, Gillman MW, Hennekens $\mathrm{CH}$, et al. Birthweight and the risk for type 2 diabetes mellitus in adult women. Ann Intern Med. 1999;130(4 Pt 1):278-84.

28. Yajnik CS. Nutrition, growth, and body size in relation to insulin resistance and type 2 diabetes. Curr Diab Rep. 2003;3(2):108-14.

29. Lithell HO, McKeigue PM, Berglund L, Mohsen R, Lithell UB, Leon DA. Relation of size at birth to non-insulin dependent diabetes and insulin concentrations in men aged 50-60 years. BMJ. 1996;312(7028):406-10.

30. Phillips DI, Barker DJ, Hales CN, Hirst S, Osmond C. Thinness at birth and insulin resistance in adult life. Diabetologia. 1994;37(2):150-4.

31. Lawlor DA, Ronalds G, Clark H, Davey Smith G, Leon DA. Birth Weight Is Inversely Associated With Incident Coronary Heart Disease and Stroke Among Individuals Born in the 1950s. Circulation. 2005;112(10):1414-8.

32. Leon DA, Lithell HO, Vagero D, Koupilova I, Mohsen R, Berglund L, et al. Reduced fetal growth rate and increased risk of death from ischaemic heart disease: cohort study of 15000 Swedish men and women born 1915-29. BMJ.1998;317(7153):241-5.

33. Martyn CN, Barker DJ, Osmond C. Mothers' pelvic size, fetal growth, and death from stroke and coronary heart disease in men in the UK. Lancet. 1996;348(9037):1264-8.

34. Rich-Edwards JW, Stampfer MJ, Manson JE, Rosner B, Hankinson SE, Colditz GA, et al. Birth weight and risk of cardiovascular disease in a cohort of women followed up since 1976. BMJ. 1997;315(7105):396-400
35. Huxley RR, Shiell AW, Law CM. The role of size at birth and postnatal catch-up growth in determining systolic blood pressure: a systematic review of the literature. J Hypertens. 2000;18(7):815-31.

36. Leon DA, Johansson M, Rasmussen F. Gestational age and growth rate of fetal mass are inversely associated with systolic blood pressure in young adults: an epidemiologic study of 165,136 Swedish men aged 18 years. Am J Epidemiol. 2000;152(7):597-604.

37. Leon DA, Koupilova I, Lithell HO, Berglund L, Mohsen R, Vagero $\mathrm{D}$, et al. Failure to realise growth potential in utero and adult obesity in relation to blood pressure in 50 year old Swedish men. BMJ.1996;312(7028):401-6.

38. Nilsson PM, Ostergren PO, Nyberg P, Soderstrom M, Allebeck P. Low birth weight is associated with elevated systolic blood pressure in adolescence: a prospective study of a birth cohort of 149378 Swedish boys. J Hypertens. 1997;15(12 Pt 2):1627-31.

39. Eriksson J, Forsén T, Tuomilehto J, Osmond C, Barker D. Size at Birth, Fat-Free Mass and Resting Metabolic Rate in Adult Life. Horm Metab Res. 2002;34(02):72,6.

40. Bertram CE, Hanson MA. Animal models and programming of the metabolic syndrome. Br Med Bull. 2001;60:103-21.

41. Horton TH. Fetal origins of developmental plasticity: animal models of induced life history variation. Am J Hum Biol. 2005;17(1):34-43.

42. Langley-Evans SC, Bellinger L, McMullen S. Animal models of programming: early life influences on appetite and feeding behaviour. Matern Child Nutr. 2005;1(3):142-8.

43. Nathanielsz PW. Animal models that elucidate basic principles of the developmental origins of adult diseases. ILAR J. 2006;47(1):73-82.

44. Michael AE, Thurston LM, Rae MT. Glucocorticoid metabolism and reproduction: a tale of two enzymes. Reproduction. 2003;126(4):425-41.

45. Seckl JR, Meaney MJ. Glucocorticoid programming. Ann N Y Acad Sci. 2004;1032:63-84.

46. Yura S, Fujii S. [Obesity in offspring with maternal undernutrition during pregnancy]. Nihon Rinsho. 2006;64(4):795-803.

47. Ling C, Groop L. Epigenetics: A Molecular Link Between Environmental Factors and Type 2 Diabetes. Diabetes. 2009;58(12):2718-

48. Rivera RM, Bennett LB. Epigenetics in humans: an overview. Curr Opin Endocrinol Diabetes Obes. 2010;17(6):493-9.

49. Bouret SG. Early life origins of obesity: role of hypothalamic programming.J Pediatr Gastroenterol Nutr. 2009;48 (Suppl 1):S31-8.

50. Cottrell EC, Ozanne SE. Developmental programming of energy balance and the metabolic syndrome. Proc Nutr Soc. 2007;66(2):198-206.

51. Armitage JA, Khan IY, Taylor PD, Nathanielsz PW, Poston L. Developmental programming of the metabolic syndrome by maternal nutritional imbalance: how strong is the evidence from experimental models in mammals? J Physiol. 2004;561(2):355-77.

52. Lillycrop KA. Effect of maternal diet on the epigenome: implications for human metabolic disease. Proc Nutr Soc. 2011;70(1):64 72.

53. McArdle HJ, Andersen HS, Jones H, Gambling L. Fetal programming: causes and consequences as revealed by studies of dietary manipulation in rats -- a review. Placenta. 2006;27 (Suppl A):S5660

54. Mostyn A, Symonds ME. Early programming of adipose tissue function: a large-animal perspective. Proc Nutr Soc. 2009;68(4):393-400.

55. Reynolds LP, Borowicz PP, Caton JS, Vonnahme KA, Luther JS, Hammer CJ, et al. Developmental programming: the concept, large animal models, and the key role of uteroplacental vascular development. I Anim Sci. 2010;88(Suppl 13):E61-72.

56. Symonds ME, Gardner DS. Experimental evidence for early nutritional programming of later health in animals. Curr Opin Clin Nutr Metab Care. 2006;9(3):278-83.

57. Kiani A. Metabolic programming and energy metabolism during gestation, lactation and growth in small ruminants. Faculty of Life Sciences UoC, Denmark, editor.; 2007.

58. Hanson M. Birth weight and the fetal origins of adult disease. Pediatr Res. 2002;52(4):473-4.

59. Oliver MH, Jaquiery AL, Bloomfield FH, Harding JE. The effects of 
maternal nutrition around the time of conception on the health of the offspring. Soc Reprod Fertil Suppl. 2007;64:397-410.

60. Ford SP, Hess BW, Schwope MM, Nijland MJ, Gilbert JS, Vonnahme $\mathrm{KA}$, et al. Maternal undernutrition during early to mid-gestation in the ewe results in altered growth, adiposity, and glucose tolerance in male offspring. J Anim Sci. 2007;85(5):1285-94.

61. Gopalakrishnan GS, Gardner DS, Rhind SM, Rae MT, Kyle CE, Brooks AN, et al. Programming of adult cardiovascular function after early maternal undernutrition in sheep. Am J Physiol Regul Integr Comp Physiol. 2004;287(1):R12-20.

62. Gardner DS, Tingey K, Van Bon BW, Ozanne SE, Wilson V, Dandrea $\mathrm{J}$, et al. Programming of glucose-insulin metabolism in adult sheep after maternal undernutrition. Am J Physiol Regul Integr Comp Physiol. 2005;289(4):R947-54

63. Husted SM, Nielsen MO, Tygesen MP, Kiani A, Blache D, Ingvartsen KL. Programming of intermediate metabolism in young lambs affected by late gestational maternal undernourishment. Am J Physiol Endocrinol Metab. 2007;293(2):E548-57.

64. Kiani A, Nielsen MO, Tauson AH, Tygesen MP, Husted SM, Chwalibog A. Long-term effects of foetal undernutrition on intermediary metabolism in growing lambs. Arch Anim Nutr. 2011;65(1):4654.

65. Clarke L, Yakubu DP, Symonds ME. Influence of maternal bodyweight on size, conformation and survival of newborn lambs. Reprod Fertil Dev. 1997;9(5):509-14.

66. Kiani A, Chwalibog A, Tygesen MP, Nielsen MO. Effect of undernutrition in foetal life on energy expenditure during gestation in ewes. Arch Anim Nutr. 2008;62(2):117-26.

67. Jørgensen W, Gam C, Andersen JL, Schjerling P, Scheibye-Knudsen $\mathrm{M}$, Mortensen $\mathrm{OH}$, et al. Changed mitochondrial function by pre-and/or postpartum diet alterations in sheep. Am J Physiol Endocrinol Metab. 2009;297(6):E1349-E57.

68. Schwartz MW. Brain pathways controlling food intake and body weight. Exp Biol Med (Maywood). 2001;226(11):978-81.

69. Adam CL, Findlay PA, Chanet A, Aitken RP, Milne JS, Wallace JM. Expression of energy balance regulatory genes in the developing ovine fetal hypothalamus at midgestation and the influence of hyperglycemia. Am J Physiol Regul Integr Comp Physiol. 2008;294(6):R1895-900.

70. Muhlhausler BS, McMillen IC, Rouzaud G, Findlay PA, Marrocco EM, Rhind SM, et al. Appetite regulatory neuropeptides are expressed in the sheep hypothalamus before birth. J Neuroendocrinol. 2004;16(6):502-7.

71. McMillen IC, MacLaughlin SM, Muhlhausler BS, Gentili S, Duffield JL, Morrison JL. Developmental origins of adult health and disease: the role of periconceptional and foetal nutrition. Basic Clin Pharmacol Toxicol. 2008;102(2):82-9.

72. Muhlhausler BS, Adam CL, Findlay PA, Duffield JA, McMillen IC. Increased maternal nutrition alters development of the appetite-regulating network in the brain. FASEB J. 2006;20(8):1257-9.

73. Bispham J, Gardner DS, Gnanalingham MG, Stephenson T, Symonds ME, Budge $\mathrm{H}$. Maternal nutritional programming of fetal adipose tissue development: differential effects on messenger ribonucleic acid abundance for uncoupling proteins and peroxisome proliferator-activated and prolactin receptors. Endocrinology. 2005;146(9):3943-9.

74. Budge H, Gnanalingham MG, Gardner DS, Mostyn A, Stephenson T, Symonds ME. Maternal nutritional programming of fetal adipose tissue development: long-term consequences for later obesity. Birth Defects Res C Embryo Today. 2005;75(3):193-9.

75. Stocker CJ, Arch JR, Cawthorne MA. Fetal origins of insulin resistance and obesity. Proc Nutr Soc. 2005;64(2):143-51.

76. Cripps RL, Martin-Gronert MS, Ozanne SE. Fetal and perinatal programming of appetite. Clin Sci (Lond). 2005;109(1):1-11.

77. Metges CC. Early nutrition and later obesity: animal models provide insights into mechanisms. Adv Exp Med Biol. 2009;646:10512.

78. Gardner DS, Rhodes P. Developmental origins of obesity: programming of food intake or physical activity? Adv Exp Med Biol. 2009;646:83-93.

79. Bouret SG. Leptin, nutrition, and the programming of hypothalamic feeding circuits. Nestle Nutr Workshop Ser Pediatr Program. 2010;65:25-35; discussion -9.

80. Vickers MH, Gluckman PD, Coveny AH, Hofman PL, Cutfield WS, Gertler A, et al. Neonatal leptin treatment reverses developmental programming. Endocrinology. 2005;146(10):4211-6.

81. Adam CL, Bake T, Findlay PA, Milne JS, Aitken RP, Wallace JM. Effects of altered glucose supply and adiposity on expression of hypothalamic energy balance regulatory genes in late gestation growth restricted ovine fetuses. Int J Dev Neurosci. 2011;29(7):775-81.

82. Prentice AM, Goldberg GR. Energy adaptations in human pregnancy: limits and long-term consequences. Am J Clin Nutr. 2000;71(5 Suppl):1226S-32S.

83. Kiani A, Chwalibog A, Tauson A-H, Nielsen MO. Impact of energy and protein restriction on energy expenditure of gestation in twin-bearing ewes. Anim Sci J. 2008;79(2):218-25.

84. Prentice AM, Poppitt SD, Goldberg GR, Prentice A. Adaptive strategies regulating energy balance in human pregnancy. Hum Reprod Update. 1995;1(2):149-61.

85. Bauer MK, Breier BH, Harding JE, Veldhuis JD, Gluckman PD. The fetal somatotropic axis during long term maternal undernutrition in sheep: evidence for nutritional regulation in utero. Endocrinology. 1995;136(3):1250-7.

86. Butte NF, King JC. Energy requirements during pregnancy and lactation. Public Health Nutr. 2005;8(7A):1010-27.

87. Heini A, Schutz Y, Jequier E. Twenty-four-hour energy expenditure in pregnant and nonpregnant Gambian women, measured in a whole-body indirect calorimeter. Am J Clin Nut. 1992;55(6):1078-85.

88. Kiani A, Chwalibog A, Nielsen MO, Tauson AH. Partitioning of late gestation energy expenditure in ewes using indirect calorimetry and a linear regression approach. Arch Anim Nutr. 2007;61(3):168-78.

89. Daenzer M, Ortmann S, Klaus S, Metges CC. Prenatal high protein exposure decreases energy expenditure and increases adiposity in young rats. J Nutr. 2002;132(2):142-4.

90. Metges CC. Longterm effects of pre- and postnatal exposure to low and high dietary protein levels. Evidence from epidemiological studies and controlled animal experiments. Adv Exp Med Biol. 2005;569:64-8.

91. Bellinger L, Sculley DV, Langley-Evans SC. Exposure to undernutrition in fetal life determines fat distribution, locomotor activity and food intake in ageing rats. Int J Obes (Lond). 2006;30(5):729-38.

92. Vickers MH, Breier BH, Cutfield WS, Hofman PL, Gluckman PD. Fetal origins of hyperphagia, obesity, and hypertension and postnatal amplification by hypercaloric nutrition. Am J Physiol Endocrinol Metab. 2000;279(1):E83-7. 